\title{
EKONOMI SOSIALISME DAN KAPITALISME
}

\section{Oleh:}

\author{
Nurul Wahida Aprilya (90100118110) \\ Fakultas Ekonomi dan Bisnis Islam UIN Alauddin Makassar \\ e-mail:wahidaprilya@gmail.com
}

Sistem ekonomi sosialis mulai diutarakan oleh Karl Marx dalam bukunya Das Kapital. Marx lahir dengan nama Karl Heinrich Marx, sebagai pencetus aliran filsafat marxisme ini lahir pada 5 mei 1818 di kota Trier-Rusia sebelah perbatasan barat Jerman. ${ }^{1}$ Karl Marx dalam bukunya Das Kapital mengkritik sistem ekonomi kapitalis yang dikatakan telah gagal mewujudkan sebuah sistem ekonomi yang stabil. ${ }^{2}$ Sistem ekonomi sosialis merupakan kebalikan dari sistem ekonomi kapitalis. Sosialisme merupakan sistem ekonomi yang dimana segala kagiatan ekonominya diatur oleh pemerintah dan perencanan terpusat dari pemerintah. Pengertian sosialisme ini sangat benbanding balik dari kapitalisme, dimana sistem perekonomiannya memberikan kebebasan secara penuh kepada setiap orang untuk melaksanakan kegiatan perekonomian. Menurut Karl Marx, manusia itu merupakan makhluk sosial maka dari itu aktivitas ekonomi tidak boleh dikuasi oleh individu tapi harus dikelola bersama-sama yang diatur oleh negara. Jadi marx ini memperkenalkan sosialisme sebagai sistem ekonomi terpusat dimana pemerintah memegang peranan paling penting atau dominan dalam pengaturan kegiatan ekonomi.

Berbicara tentang kapitalisme seolah tak mungkin untuk mengabaikan Adam Smith. Adam smith merupakan pemikir pertama yang mengembangkan pentingnya

1 Kambali, M, "Pemikiran Karl Marx Tentang Struktur Masyarakat (Dialektika Infrastruktur dan Suprastruktur)," Jurnal Pemikiran dan Penelitian Ekonomi Islam, Vol. 8 No. 2, 2020, h. 65

2 Boy Syamsul Bakhari, "Sistem Ekonomi Islam dalam Perbandingan," Jurnal Agama dan Ilmu Pengetahuan, Vol. 8 No. 1, 2011. h. 44 
Akumulasi Kapital dalam pengembangan ekonomi. Teori Adam Smith tentang Labour Theory of Value itu kemudian menjadi dasar kapitalisme. ${ }^{3}$ Ernest mandel dalam buku Bagong Suyanto yang berjudul "Sosiologi Ekonomi: Kapitalisme dan Konsunsi di Era Masyrakat Post Modernisme" membahs lebih perinci dan mengajukan lima ciri pokok dari ekonomi kapitalisme. Pertama, ditingkat produksi, corak kapitalis adalah produksi komoditas, untuk meraih keuntungan yang sebesar-besarnya. Kedua, produksi dilandasi kepemilikan pribadi. Ketiga, produksi dioperasinalkan dalam rangka meraih menguasai pasar yang berada dibawah kendali persaingan. Keempat para kapitalis beupaya merauk keuntungan yang sebesar-besarnya dengan cara melakukan. Kelima, tujuan terakhir dari produksi adalah akumulasi kapital. ${ }^{4}$

Kapitalisme adalah sistem ekonomi yang dimana kegiatan ekonominya dilakukan sesuai dengan mekanisme pasar dan campur tangan pemerintah sangat minim. Setiap individu kapitalisme mempunyai kebebasan penuh dalam melakukan kegiatan yang memberikan keuntungan bagi dirinya. Menurut Adam Smith pasar bebas akan memberikan keuntungan bagi semua orang, tapi menurut Karl Marx itu tidak. Nah disinilah munculnya kritik Karl Marx terhadap kapitalisme. Ia mengatakan bahwa pasar bebas ini akan menimbulkan konsekuensi yang sangat negatif bagi masyrakat, yaitu melebarnya kesenjangan sosial. Jadi pasar bebas ini hanya akan menguntungkan kaum borjuis atau para pemegang alat produksi ataupun para pemilik modal itu menjadi kaya makin lebih kaya lagi, sedangkan para pekerja atau buruh itu sangat dirugikan dengan mekanisme pasar bebas ini.

\footnotetext{
${ }^{3}$ Kartini, Mulawan, \& Yuningsih, "Kapitalisme Pedesaan Di Kawasan Ekonomi Khusus
} (KE) Tanjung Lesung Kabupaten Pandeglang Propinsi Banten," CosmoGov: Jurnal Ilmu Pemerintahan, Vol. 3 No. 1, 2017. h. 57

4 Sirajuddin \& Tamsir, "Rekonstruksi Konseptual Kepemilikan Harta Perspektif Ekonomi Islam (Studi Kritis Kepemilikan Harta Sistem Ekonomi Kapitalisme)," Laa Maisyir: Jurnal Ekonomi Islam, Vol.6 No.2, 2019. h. 213. 
Berikut beberapa Indikator-indikator Kunci Dasar Ekonomi, yaitu:

Statistik No.1 : Kekayaan 359 orang terkaya di Dunia setara dengan kekayaan 2,9 milyar orang-orang termiskin di Dunia. Terdapat 5 milyar penduduk bumi dan kita hanya dapat mengambil sebanyak 359 orang yang terbilang kaya, dimana perkiraan kekayaan mereka setara dengan jumlah kekayaan separuh lebih jumlah penduduk bumi. Nah jadi disini terjadi yang namnya kesenjangan sosial atau pendapatan antara oarang kaya dan miskin.

Statistik No.2 : Total kekayaan 3 orang terkaya di Dunia bila digambungkan sama dengan GDP dari 48 negara termiskin.

Statistik No.3 : Untuk mengatasi permasalahn penduduk dunia dalam ketersediaan kebutuhan dasarnya (makanan, air, pendidikan, kesehatan) dan untuk mengatasi kelaparan, kekurangan gizi, dan wabah-wabah penyakit, yang dibutuhkan adalah 4\% dari akumulasi kekayaan dari 255 orang terkaya dunia.

Statistik No.4 : Untuk memenuhi kebutuhan dunia, kesehatan dan makanan, keseluruhan dibutuhkan \$13 Milyar. Jumlah ini setara dengan total pengeluaran pembelian parfum di Eropa.

Fakta-fakta diatas menunjukkan bahwa sesungguhnya terdapat kontradiksi atau kesenjangan yang sangat mencengangkan dalam masyrakat kita saat ini. Bila kita lihat dari 300 tahun terkahir kontradiksi yang sama juga terjadi. Dimana apa yang disebut dengan Pembangungan selalu sejalan dengan Ketertinggalan.

Definisi asli dari Kapitalisme adalah suatu sistem ekonomi (sosial) yang bercirikan frofit motive dan kontrol terhadap sarana produksi, distribusi dan pertukaran oleh kepemilikan pribadi. Definisi ini bisa menjadi titik berangkat bagi kita, karena disitu dikatan bahwa sistem sosial dan ekonomi yang ada saat ini dicirikan dengan provite motive. Disini lota tidak dijelaskan siapa yang memiliki profit motive ini tetapi dikalimat 
selanjutnya dikatakan bahwa kontrol terhadap sarana produksi, distribusi, dan pertukaran barang oleh privete ownership. Dominasi perinsip keuntungan dan private property sebenarnya saling terkait.

Berikut ini rumus dari kapitalisme (The Money Circuit of Capital) untuk mencari keuntungan, yaitu:

$\mathrm{M}-\mathrm{C}-\mathrm{M}^{1} \quad$ Dimana $: \mathrm{M}=$ uang modal, $\mathrm{C}=$ nilai komoditas yang dibeli dengan uang, dan $\mathrm{M}^{1}$ = hasil uang yang lebih banyak dari hasil komoditas.

Karl Marx melihat dalam kapitalisme mengenal siklus modal dengan $\left(\mathrm{M}^{1}-\mathrm{C}-\mathrm{M}^{2}\right)$, nah rumus tersebut menggambarkan bahwa bagaimana modal yang sedikit $\left(\mathrm{M}^{1}\right)$ menghasilkan komoditas (C) yang dibutuhkan oleh konsumen dengan harga yang mahal $\left(\mathrm{M}^{2}\right) .{ }^{5}$ Uang harus menjadi komoditi $\mathrm{C}$ dan komoditi harus menjadi uang lagi dengan cara dijual kembali. Orang kapitalis tidak berhenti begitu saja jika sudah dapat M', tetapi motif untuk mencari keuntungnya ia membeli lagi komoditas C' dalam rangka utnuk mendapatkan uang lebih banyak M", begitulah seterusnya sampai muncul namanya Akumulasi yang tak terhingga. Jadi orang kapitalis jika mencari keuntungan itu tidak ada batasnya, ini seusai dengan contoh gambar diatas bahwa kita bisa menambahkan M dan C secara terus menerus karena tidak ada batasan untuk mencari keuntungan.

Jika kita kembangkan lagi rumus dari Money circuit of capital untuk melihat hubungan antara profit dan produksi, maka pada Produksi untuk profit itu mengandalkan dua hal yang pertama : sarana produksi, distribusi dan pertukaran harus terkonsentarsi pada satu tangan dan yang kedua : pasar tenaga kerja, sebuah pasar dimana orang-orang

5 Siti Mahrumi, Andi Muh Nur, Dewi Indra Rini. “Analisis Biaya Promosi Terhadap Volume Penjualan Mobil Avanza Pada PT. Toyota Hadji Kalla Makassar”. Jurnal Ekonomi Balance Fakultas Ekonomi Dan Bisnis. Vol. 13 No. 1, 2017. h. 2 
mencari kerja untuk mendapatkan upah. Nah tanpa kedua hal ini maka Profit Movie tidak akan bisa menghasilkan keuntungan yang sebenarnya.

Berikut rumusnya:

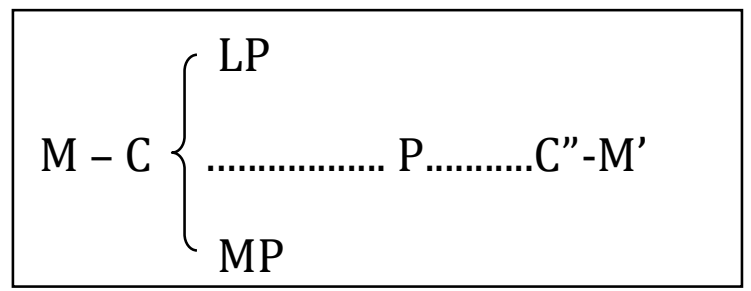

Dimana C dibagi dua yaitu LP (labour power) atau biasa disebut tenaga kerja, sedangkan MP (means of production) atau biasa disebut dengan sarana produksi. Jadi ketika LP dan MP disatukan maka terjadilah proses produksi. Proses ini disimbolkan dengan $\mathrm{P}$, karena disini kita berbicara dengan energi hidup yang masuk ke proses kerja. C' adalah komoditi baru yang dihasilkan juga dengan nilai baru. Kemudian dijual dan menghasikan $\delta \mathrm{M}$ atau $\mathrm{M}$ '. Karakter akumulasi tanpa batas inilah biasa disebut juga dengan kerja tanpa batas, karena kerja merupakan moto dalam masyrakat kapitalis. 


\section{DAFTAR PUSTAKA}

Bakhri, B. S. (2011). Sistem Ekonomi Islam dalam Perbandingan. Al-Hikmah: Jurnal Agama dan Ilmu Pengetahuan, 8(1), 42-49.

Dewi, S., \& Rini, I. (2017) Analisis Biaya Promosi Terhadap Volume Penjualan Mobil Avanza Pada PT. Toyota Hadji Kalla Makassar. Jurnal Ekonomi Balance Fakultas Ekonomi Dan Bisnis, 13(1).

Kambali, M. (2020). Pemikiran Karl Marx Tentang Struktur Masyarakat (Dialektika Infrastruktur dan Suprastruktur). Jurnal Pemikiran dan Penelitian Ekonomi Islam, $8(2), 63-80$.

Kartini, D. S., Mulawan, R., \& Yuningsih, N. Y. (2017) "Kapitalisme Pedesaan Di Kawasan Ekonomi Khusus (KE) Tanjung Lesung Kabupaten Pandeglang Propinsi Banten,” CosmoGov: Jurnal Ilmu Pemerintahan, 3(1), 55-64.

Sirajuddin, S., \& Tamsir, T. (2019). Rekonstruksi Konseptual Kepemilikan Harta Perspektif Ekonomi Islam (Studi Kritis Kepemilikan Harta Sistem Ekonomi Kapitalisme), Laa Maisyir: Jurnal Ekonomi Islam, 6(2), 211-225. 